\title{
BOGUMIE STRĄCZEK
}

(Kraków)

\section{KIM JEST CZŁOWIEK? \\ GIRARD I PATOČKA O PODNOSZENIU SIE Z UPADKU}

Zacznę od przypowieści biblijnej, która moim zdaniem jest ważna dla zrozumienia pojęcia człowieczeństwa:

Jezus udał się na Górę Oliwną, ale o brzasku zjawił się znów w świątyni. Cały lud schodził się do Niego, a On usiadłszy nauczał ich. Wówczas uczeni w Piśmie i faryzeusze przyprowadzili do Niego kobietę, którą pochwycono na cudzołóstwie, a postawiwszy ją pośrodku, powiedzieli do Niego: Nauczycielu, tę kobietę dopiero pochwycono na cudzołóstwie. W Prawie Mojżesz nakazał nam takie kamienować. A Ty co mówisz? Mówili to wystawiając Go na próbę, aby mieli o co Go oskarżyć. Lecz Jezus nachyliwszy się pisał palcem po ziemi. A kiedy w dalszym ciągu Go pytali, podniósł się i rzekł do nich: Kto z was jest bez grzechu, niech pierwszy rzuci na nią kamień. I powtórnie nachyliwszy się pisał na ziemi. Kiedy to usłyszeli, wszyscy jeden po drugim zaczęli odchodzić, poczynając od starszych, aż do ostatnich. Pozostał tylko Jezus i kobieta, stojąca na środku. Wówczas Jezus podniósłszy się rzekł do niej: Kobieto, gdzież oni są? Nikt cię nie potępił? A ona odrzekła: Nikt, Panie! Rzekł do niej Jezus: I Ja ciebie nie potępiam. - Idź, a od tej chwili już nie grzesz ${ }^{1}$.

Ta powszechnie znana historia stanowi jeden z najważniejszych passusów biblijnych. Zdaniem francuskiego myśliciela René Girarda jest ona w istotnej opozycji do mitycznych przypowieści o kamienowaniu. W nich bowiem, jak chociażby w micie o Apolloniosie z Tyany, dochodzi do ukamienowania ofiary, a przewodniczaccy całemu widowisku guru, dodatkowo podjudza agresywny tłum. Ta-

1 J 8: 1-11. 
kie kolektywne morderstwo jest zresztą punktem kulminacyjnym licznych tradycji mitologicznych. Jest ono również tematem samej Ewangelii, choć nie wyżej cytowanego fragmentu. W nim bowiem Jezus robi wszystko, aby ocalić kobietę i nie dopuścić do rozlewu krwi. Czyni to posługując się symboliką pierwszego kamienia: „Kto z was jest bez grzechu, niech pierwszy rzuci na nią kamień". Wypowiadając te słowaJezus stawia oskarżycieli w dramatycznej sytuacji wyboru, wyboru, który jest indywidualna decyzja, każdego, który w swej dłoni trzyma kamień.

Dlaczego symbolika pierwszego kamienia okazuje się decydująca? Zwracając na niego uwagę, Jezus z pierwszego kamienia czyni pierwszą przeszkodę udaremniającą kamienowanie: „Im bardziej ci, którzy myślą o rzuceniu pierwszego kamienia - pisze Girard - będą sobie zdawać sprawę z ciążącej na nich odpowiedzialności, tym więcej szans na to, że go wypuszczą" 2. Pierwszy kamień okazuje się decydujaccy, „ponieważ najtrudniej go rzucić” ${ }^{3}$. Rzucony raz, pociągnie za sobą lawinę, która sprowadzi na kobietę nieuniknioną śmierć. Odpowiedź oprawców jest jednak wymowna: „Kiedy to usłyszeli, wszyscy jeden po drugim zaczęli odchodzić, poczynając od starszych, aż do ostatnich".

Skąd ta radykalna zmiana w nastawieniu oprawców? Czy całą sytuację należy odczytywać w kategoriach kolejnego cudu? Przeciwnie. Nie dostrzegamy tu nic cudownego. Przynajmniej nie w tym sensie, w jakim mamy do czynienia w Kanie Galilejskiej podczas przemiany wody w wino. W całej tej sytuacji Jezus raczej przypomina starożytnego mędrca, spisującego swe myśli na piasku, niż cudotwórcę i maga. Przemawia za tym również fakt, iż wstawiając się za oskarżoną kobietą, posługuje się argumentem słowa (logos), nie zaś spektakularnym cudem. Słowa „Kto z was jest bez grzechu, niech pierwszy rzuci na nią kamień" nie są zaklęciem hipnotyzującym oprawców. Jezus wypowiada je, aby uzmysłowić oprawcom „prawdziwą zasadę nie tylko starożytnych aktów kamienowania, lecz wszystkich masowych, starożytnych i nowożytnych zjawisk" ${ }^{4}$. Czy chodzi jedynie o uświadomienie ludziom niebezpieczeństwa, jakim jest dla nich niekontrolowana przemoc, która niewątpliwie panowała w Izraelu w czasach rzymskiej okupacji?

W innym fragmencie, W Ewangelii św. Mateusza Jezus przemawiajacy do tłumu, ukazywany jest jako ten, który przyszedł, aby wypowiedzieć „rzeczy ukryte od założenia świata". To bowiem przezwyciężanie iluzji, w jakiej pogrążony był

\footnotetext{
2 R. Girard, Widziałem szatana spadajacego z nieba jak blyskawica, tłum. E. Burska, Warszawa 2002, s. 68 .

3 Tamże.

4 Tamże, s. 69.
} 
człowiek od zarania dziejów, stanowi najważniejsze przesłanie Ewangelii. W mitach ofiara przemocy przedstawiana jest bowiem jako monstrualny winowajca, który zasługuje na społeczne potępienie. Ewangelie natomiast zapoczątkowały to, co jeden z uczniów Girarda nazwał „najbardziej radykalną rewolucją w dziejach, polegającą na dostrzeżeniu znaczenia pokrzywdzonych" ${ }^{5}$. Mity religii archaicznych krążą wokół kolektywnego mordu, jednak nigdy nie ukazują go wprost, gdyż są one wersją tego wydarzenia opowiedzianą z punktu widzenia prześladowców. Biblia natomiast zawiera wiele historii, które opowiadane są z perspektywy ofiar, co stanowi proces powolnego odchodzenia od przemocy i niezwykle istotny moment ewolucji kulturowej.

Przyglądnijmy się raz jeszcze historii o kobiecie cudzołożnej. Zauważmy, że symbolika pierwszego kamienia nie ma jedynie negatywnych konotacji. Jezus w swoim nauczaniu nie ucieka się tylko i wyłącznie do krytyki zjawisk, które przyczyniały się do upadku współczesnego mu społeczeństwa, będącego obrazem upadającego człowieka. Podobnie jak w innych miejscach, także i tu w jego słowach odnajdujemy przesłanie pozytywne, a więc wskazówkę, jak należy postępować. Wezwanie do spojrzenia we własne sumienie, by poznać siebie jest w pierwszej kolejności wezwaniem do odpowiedzialności, do zatroszczenia się o własne życie. Jezus powiada bowiem: „kto z was jest bez winy”. Treść tego wezwania ma znaczenie zasadnicze, nadające odpowiedzialności wymiar indywidualistyczny. To właśnie ono skłania wcześniej pałających żądzą przemocy, do „porzucenia kamienia", do zmiany dotychczasowego sposobu życia.

Na tę więź między spojrzeniem we własne wnętrze a wezwaniem do odpowiedzialności zwraca uwagę Patočka w jednym ze swoich Esejów heretyckich z filozofii dziejów. Wezwanie do odpowiedzialności jest wezwaniem wypływającym od wewnatrz. Pozostaje ono zawsze w ścisłym związku z procesem formowania wolności i podmiotowości człowieka, a jednocześnie z wysiłkiem przezwyciężania siebie. Takie przezwyciężanie ma przede wszystkim charakter podnoszenia się z upadku, który czeski myśliciel uznaje za pojęcie „nieodłączne od życia ludzkiego w jego wewnętrznej naturze, w samym jego byciu" 6 .

Upadek i podnoszenie się z upadku są zatem wpisane w ludzki modus vivendi. Upadek, a raczej ludzkie bycie w upadku oznacza „takie życie, z którego uchodzi sam wewnętrzny nerw jego funkcjonowania, które jest uszkodzone w swym najistotniejszym rdzeniu, które każdym swoim krokiem i czynem pustoszy siebie i okalecza" 7. Upadek nie jest ani właściwym, ani prawdziwym kontekstem życia człowieka. Jest jednak jego dziełem, aktem samowyobcowania, ucieczką.

\footnotetext{
5 G. Bailie, Violence Unveiled, New York 1995: Crossroad s. 21.

6 J. Patočka, Eseje heretyckie z filozofii dziejów, tłum. J. Zychowicz, Warszawa 1998, s. 131n.

7 Tamże, s. 132 .
} 
Znamienne jest jednak to, że wyobcowanie może się pogłębić, ale już nie na skutek ucieczki od odpowiedzialności, lecz demonicznego porwania. Patočka nieustannie podkreśla, iż człowiek jest istotą usytuowaną w kontekście samoujarzmiania przez życie, pracy, walki o siebie. Jest to kontekst etyczny, w który człowiek został wrzucony: „«zadecydowano o nas» zanim sami się «zdecydowaliśmy»”. Jest to więc kontekst typowo ludzki, obcy zwierzętom i bóstwom. Pojęcie daimon, jak pokazuje Derrida w znakomitym komentarzu do analizowanego przez nas tekstu, „przekracza granice, które oddzielają zwierzę, istotę ludzką i istotę boską" 8 . Stąd też demonizm oznaczać będzie sferę, w której nie pojawia się nakaz odpowiadania za. „Inaczej mówiąc, demonizm pierwotnie definiuje się przez nieodpowiedzialność, albo jak kto woli - przez brak odpowiedzialności" 9 . Jest to sfera pożądliwości, entuzjazmu, w skutek którego człowiek zostaje wyrwany z właściwego mu kontekstu etycznego, przez co zatraca się samoświadomość i poczucie odpowiedzialności. Jest to sfera orgiazmu i namiętności, a więc sfera niekontrolowanego pożądania, owej niebezpiecznej epithymia, przed którą ostrzegał już Platon. Zagrożenie to zostało przedstawione w Fajdrosie za pomocą wymownego obrazu niewychowanego i silnego konia, będącego utrapieniem dla kierującego rydwanem woźnicy:

Konia ma jednego doskonałego, z pięknej i dobrej rasy, a drugiego z całkiem przeciwnej, rumaka zupełnie tamtemu przeciwnego [...] koń, który ma w sobie zło, ciągnie w dół, ku ziemi ciągnie, jeśli go woźnica dobrze nie wychował. Tu się dusza najwięcej trudzić i wytężać musi ${ }^{10}$.

Platon mówi o człowieku poddanym swym najokrutniejszym żądzom (epithymia), który zostaje przez nie porwany, niczym woźnica nie mogący zapanować nad rozjuszonym koniem. Ów stan wprawia go w chwilowy entuzjazm i egzaltacje. W miarę pogłębiania się obłędu, dusza staje się coraz bardziej skłonna do zupełnego poddania się epithymia; zostaje porwana $i$ pokonana, a ten stan przyjmuje jako swój własny, „normalny”, wrastający głęboko w naturę człowieczeństwa. Słynny fragment z siódmej księgi Politei, opisuje konsekwencję omawianego zagrożenia: niewolniczą wegetację na dnie jaskini.

Patočka dalej dostrzega istotne analogie pomiędzy orgiastycznym doświadczeniem a misterium sakralnym. Mówi o tym posługując się cytatem z Elementarnych form życia religijnego Durkheima, gdzie znajduje opis obchodzenia święta przez ludy australijskich aborygenów:

\footnotetext{
8 J. Derrida, Herezja, tajemnica i odpowiedzialność: Europa Jana Patočki, tłum. A. Drop, „Logos i Etos”, 1/1993, s. 138.

9 Tamże.

10 Platon, Fajdros 247b.
} 
Można sobie łatwo wyobrazić, iż dotarłszy do tego stopnia egzaltacji człowiek już siebie nie poznaje. Ponieważ czuje się opanowany, ciągnięty przez jakąś zewnętrzną siłę, która sprawia, że myśli on i działa inaczej niż w normalnym czasie, ma wrażenie, że nie jest już sobą. Wydaje mu się, że uległ odnowie: ozdoby, w które się spowija, maski, którymi zakrywa swoją twarz, wyrażają na zewnątrz tę wewnętrzną przemianę - jeśli się do niej nie przyczyniają. A ponieważ wszyscy jego towarzysze czują się tak samo przemienieni... wygląda to wszystko tak, jak gdyby rzeczywiście został on przeniesiony do jakiegoś osobliwego świata, zupełnie innego niż ten, w którym normalnie żyje. Jakże takie doświadczenia, zwłaszcza powtarzane codziennie całymi tygodniami, mogłyby nie przekonywać go o tym, iż faktycznie istnieją dwa różne i nieporównywalne światy? W jednym z nich wlecze on mozolnie swoje codzienne życie; do drugiego wystarczy tylko wstąpić, by stanąć w obliczu niezwykłych możliwości, które go galwanizują aż do frenezji. Pierwszy to świat świecki, drugi zaś jest światem rzeczy świętych ${ }^{11}$.

Opisane powyżej przez Durkheima przejście od doświadczenia orgiastycznego do misterium sakralnego znajduje również swoją interpretację w antropologii René Girarda. Autor Kozła ofiarnego pozostaje pod wpływem tego francuskiego socjologa, zwłaszcza jeśli chodzi o koncepcję sacrum, rozumianego jako wytwór ludzkiej wyobraźni:

Sacrum jest hipotezą ludzkiego umysłu, który widzi, że przekraczają go zewnętrzne, jak mu się wydaje moce. Ta wyobrażona moc, dla jakiś nieznanych racji, czyni co chce ze wspólnotą ${ }^{12}$.

Wydaje się jednak, że Girard w archaicznych misteriach sakralnych dostrzega to, co umyka uwadze zarówno Durkheima jak i Patočki, a mianowicie mimetyczny charakter owych obrzędów. To właśnie w mimetyzmie tkwi źródło iluzorycznego wyobrażenia o sacrum.

Czym jest mimetyzm? Jest to „proces, który rozpoczyna się pragnieniem mimetycznym, trwa w rywalizacji, dochodzi do wrzenia w kryzysie mimetycznym lub ofiarniczym i kończy się rozwiązaniem, jakim jest kozioł ofiarny" 13 Naśladownictwo (gr. mimesis) stanowi bowiem nieodłączny element ludzkiej natury. Jest ono wypadkową najbardziej pierwotnych, nieuświadomionych, wrodzonych i witalnych dynamizmów, leżących u źródeł wszelkich motywacji i decyzji. Człowiek poprzez naśladowanie przyswaja język, rozwija zdolność uczenia się i wiedzę. Ale mimesis

\footnotetext{
11 E. Durkheim, Les formes elemetaires de la vie religieuse, Paris 1968, s. 312-313.

12 R. Girard, Rzeczy ukryte od założenia świata, tłum. M. Goszczyńska, „Literatura na świecie", nr 12 (149), s. 108.

13 R. Girard, Poczatki kultury, tłum. M. Romanek, Kraków 2006, s. 62.
} 
ma również swoje drugie, złowrogie oblicze. Stanowi źródło wszelkiej iluzji, ślepej fascynacji przemocą, która może jednocześnie przerodzić się w szaleńczą nienawiść do siebie samego, źródło zniewolenia przez pożądliwość, gwałt, rywalizację i sacrum.

Przypomnijmy, że również u Platona mimesis oraz jej związek z epithymia przyczynia się do fałszywego obrazu bogów ${ }^{14}$. Girard twierdzi jednak, iż owa iluzja krystalizuje się wokół mechanizmu ofiary, który jest konsekwencją naśladownictwa i związanej z nim rywalizacji, przez co odcina się od platońskich spekulacji dotyczących zgubnego działania poetów w polis. Pojęcie „mechanizm” wskazuje, że chodzi tu raczej o pewien nieuświadomiony system, całkowicie warunkujący ludzki sposób myślenia i działania, wskutek którego jednostka staje się częścią składową pewnej struktury, kierowanej przez absolutne prawo. Przyjrzyjmy się bliżej całemu procesowi.

W Rzeczach ukrytych od założenia świata czytamy, że w trakcie antropogenezy człowiek ze swojej zwierzęcości odziedziczył dyspozycję zachowań mimetycznych, które na dalszym etapie przyjmują formę mimetycznej pożądliwości. Człowiek będąc istotą pożądającą, która jednak swych pragnień nie potrafi uzasadnić, potrzebuje w świecie przewodnika, fascynującego autorytetu. Znajduje go w Innym, którego naśladuje w pogoni za przedmiotem pragnienia. Ów zmysł naśladowczy, stanowiący prainstynkt, silniejszy nawet od instynktu seksualnego jest, zdaniem Girarda, siłą leżącą u podstaw wszelkich ludzkich motywacji i decyzji, wszelkiego poznania i działania, słowem - jest élan vital ludzkiego bytu. Ta dyspozycja przeradza się w rywalizację, w momencie zawłaszczenia przedmiotu, który następnie spotyka się z symetrycznym pożądaniem innego osobnika. Podmiot pożąda przedmiotu, ponieważ pożąda go rywal. Przykładem jest chociażby opisana przez Freuda w Totem $i$ tabu sytuacja pierwotnej hordy, w której dochodzi do rywalizacji o względy matki. Zdaniem Girarda źródłem rywalizacji nie jest, jak chciał Freud, instynkt seksualny, lecz wzajemne naśladownictwo pożądania.

Wniosek, jaki ostatecznie wyciąga Girard, ukazuje zależności między mimetyczną pożądliwością a rywalizacją i przemocą, która ma niezaspokojony charakter. Ten kontekst jest znamienny, gdyż pochłonięty rywalizacją podmiot nie jest zdolny do samodzielnego i odpowiedzialnego podejmowania decyzji, lecz kierowany poprzez mimetyczną siłę pożądania.

Napędzająca się rywalizacja ma również swoje społeczne reperkusje. Pochłania nie tylko jednostki, lecz również całe wspólnoty. Charakteryzuje ją dynamika kuli śniegowej. Gdy rywalizacja zaczyna się rozprzestrzeniać, przemoc totalna

14 Tenże, Rzeczy ukryte od założenia świata, wyd. cyt., s. 108. 
ma już tak duży zasięg, że zagraża istnieniu całej społeczności. Ta kolej rzeczy każdą wspólnotę musi doprowadzić do kryzysu, a nawet całkowitego wyniszczenia. Znamionami takiego kryzysu jest zniesienie wszelkich różnic, a więc to, co w swej treści zawiera przywołane wcześniej pojęcie daimon-izm. Kryzys to powszechne odróżnorodnienie, co jednoznaczne jest z oscylacją między zwierzęciem, człowiekiem a istotą boską. Skoro więc dla Girarda kultura jest uporządkowanym systemem różnic, znajdującym swe odzwierciedlanie w postaci hierarchicznego ustrukturalizowania społeczeństwa, w postaci tabu kazirodztwa, w przypisaniu jednostkom określonych ról społecznych, to zacieranie tych różnic stanowi powrót do pierwotnego stanu natury, który jest stanem wojny wszystkich przeciw wszystkim.

Kultura zdominowana przez przemoc jest więc kulturą w stanie permanentnego upadku. Ślady tego mechanizmu odnajduje Girard w mitach i rytuałach: „Początek mitu często ogranicza się do jednej cechy. Dzień miesza się z nocą. Niebo i ziemia zachowują łączność pomiędzy sobą: bogowie chodzą wśród ludzi, zaś ludzie wśród bogów. Nie ma wyraźnej różnicy pomiędzy bogiem, człowiekiem i zwierzęciem. Słońce i księżyc są bliźniaczymi braćmi; walczą nieustannie pomiędzy sobą i nie można ich od siebie odróżnić. Słońce jest zbyt blisko ziemi; susza i upały sprawiają, iż egzystencja staje się niemożliwa" ${ }^{15}$.

Społeczeństwa archaiczne wypracowały jednak metodę przezwyciężania owego kryzysu. Polega ona na zlokalizowaniu źródła społecznej traumy. Daje to początek prześladowaniom i poszukiwaniom kozła ofiarnego, który zostanie obciążony odpowiedzialnością za panujący nieład. Kolektywna przemoc wszystkich przeciw wszystkim, która grozi unicestwieniem całej wspólnoty, zostaje następnie spontanicznie i automatycznie przemieniona w przemoc wszystkich przeciw jednemu. W ten sposób wina zostaje przelana na jedną ofiarę, przyczyniając się do oczyszczenia (katharsis) wspólnoty i regeneracji społecznego porządku. Ową przemianę społeczeństwa „prymitywne” utożsamiały z przyczynowością magiczną, z nadprzyrodzoną siłą.

Antropologia Girarda w interesujący sposób tłumaczy głęboką nieufność Patočki do archaicznych misteriów sakralnych, ponieważ ich głównym motywem jest przemoc. Powiązanie ze sobą zjawisk naśladownictwa, rywalizacji i przemocy, która ostatecznie przekształca się w przerażające doświadczenie sacrum, jest dla Girarda jednocześnie źródłem konstytuowania się instytucji rytuałów ofiarniczych. Te zaś drogą ewolucji przeradzają się w orgie, sodomie, gwałty i kazirodztwa, lecz nigdy nie zrywają ze swoim pierwotnym źródłem - kolektywną przemocą. Stąd też jeszcze bardziej zrozumiałe wydaje się stwierdzenie Patočki, że „demonizm trzeba

15 Tenże, Koziol ofiarny, tłum. M. Goszczyńska, Łódź 1987, s. 148. 
odnieść do odpowiedzialności, z którac początkowo i pierwotnie nie jest związany żadną relacją" ${ }^{16}$. To zaś dokonuje się na skutek podwójnego wstrząsu: pierwszy przychodzi wraz z platonizmem i jego programem paidei, drugi za sprawą chrześcijańskiego misterium tremendum. Między jednym a drugim przewrotem istnieje jednak radykalna różnica.

Girard i Patočka dostrzegają istotny przewrót, jaki przychodzi wraz z platonizmem. Cenzura, która w Politei przybiera formę eliminacji poetów z idealnego państwa, w efekcie ma przyczynić się uformowania nowego człowieka. Wymaga to przełamania okrutnego i niemoralnego obrazu bogów, co stanowić ma „narodziny nowej kultury - już nie czysto mitologicznej, ale racjonalnej, filozoficznej" ${ }^{17}$. Tym, co Platon nazywa teologią poetów jest zdaniem Girarda „prawdziwe sacrum, prymitywne sacrum, a więc sacrum podwójne, łączące to, co przeklęte, z tym, co błogosławione" 18. Tendencja dualistyczna, z którą mamy do czynienia w platonizmie, zmierza w kierunku zachowania dobroczynnego aspektu bogów, a w gruncie rzeczy polega na „przekształceniu kryzysu w idyllę" 19.

Zarysowany w Politei scenariusz wyjścia z jaskini odpowiada temu, co w tytule tego artykułu zostało określone jako podnoszenie się z upadku. Zdaniem Patočki platońska „konwersja”, odwrócenie wzroku od wnętrza jaskini i skierowanie go w kierunku poznawalnego rozumem dobra, jest pierwszym w dziejach wprowadzeniem podmiotu w relację do odpowiedzialności:

Przypowieść ta zwłaszcza w partii dramatycznej, jest odwróceniem tradycyjnych misteriów i ich orgiastycznych obrzędów. Już te obrzędy zmierzały jeśli nie do połączenia odpowiedzialności z orgiastyką, to do ich konfrontacji, Jaskinia jest pozostałością misteryjnych zgromadzeń, jest łonem matki-ziemi. Nowa myśl Platona wyraża wolę, by opuścić łono matki-ziemi i udać się na czystą „drogę światła”, a więc podporządkować orgiazm odpowiedzialności. Dlatego droga platońskiej duszy prowadzi wprost do wieczności i do źródła wszelkiej wieczności, do słońca „dobra” ${ }^{20}$.

„Podporządkować orgiazm odpowiedzialności” oznacza tyle, co panować nad tym, co jest przyczyną egzystencjalnego upadku. Potwierdzenie dla takiej interpretacji znajdujemy w innym miejscu, gdy Patočka pisze o twardej dyscyplinie, absolutnym roszczeniu logosu. Ta dyscyplina stanowi centralny motyw platońskiej paidei. Słowo paideia sugeruje, że w pierwszej kolejności chodzi o wychowanie,

\footnotetext{
16 J. Patočka, Eseje heretyckie, s. 136.

17 R. Girard, Koziol ofiarny, s. 113.

18 Tamże.

19 Tamże.

20 J. Patočka, Eseje heretyckie..., s. 142.
} 
ujarzmianie czającego się na dnie duszy zagrożenia, panowanie logosu nad życiem człowieka, a są to inne nazwy ćwiczeń duchowych, technik medytacji, filozofii. Być może właśnie dlatego Patočka nazywa platonizm nowym misterium duszy, już nie demonicznym, lecz racjonalnym, przyjmującym formę dialogu duszy ze samą sobą. Ta rozmowa ma coś z doświadczenia mistycznego, jest tym doświadczeniem, gdyż jej treścią jest nieśmiertelność indywidualna, ,indywidualna, bo wewnętrzna, bo nieodłączna od własnego czynu" 21.

Ale owa nieśmiertelność zostaje osiągnięta nie poprzez ucieczkę od śmierci, nie ma też nic z dionizyjskiej maestrii panowania nad jej rytmem. Ta bowiem jest domeną orgiastycznych uniesień i misteriów ofiarniczych. Przeciwnie: „platoński filozof przezwyciężył śmierć zasadniczo w ten sposób, że przed nią nie uciekł, lecz śmiało patrzył jej w oczy" 22. Dlatego Sokrates z chłodnym spokojem przyjmując śmierć jest dla Platona archetypem filozofa. Filozofia jako „wyzwolenie”, jako melete tanatou, jako Sorge, jako „panowanie odpowiedzialności, a tym samym wolności" ${ }^{23}$. W tym kierunku zmierza wywód Patočki.

Nie jest to jednak ostatnie słowo w dziejach podmiotu. Platońskie misterium duszy, grecka polis, epos i tragedia zostają przezwyciężone drogą „ponownego zwrotu", który nadchodzi wraz z chrześcijaństwem, gdzie życie odpowiedzialne zostaje pojęte jako dar. Jest to moment, w którym relacja, mająca charakter poznawczy, relacja podmiot-przedmiot, dusza-dobro, przechodzi w relację osób, w relację ja-Ty, relację, którą Patočka nazywa bezinteresowną dobrocią i pełną samozaparcia miłością. Semantyka daru jest tu decydująca. Darem nie może być coś, co zostało zdobyte drogą własnego wysiłku, własnego starania. Dar ma to do siebie, że jest właśnie darem bezinteresownym, odpowiedzią, która wyprzedza pytanie, gestem, który wyprzedza prośbę. Z tej semantyki daru wyłania się jeszcze inne znaczenie. Dar jest zawsze związany $\mathrm{z}$ intencją, $\mathrm{z}$ wyjściem naprzeciw, ze spotkaniem drugiego, z doświadczeniem jego dobroci.

Ale przecież Patočka nazywa to doświadczenie spotkania misterium tremendum, doświadczeniem tajemnicy pełnej grozy. Kategoria ta od razu przywołuje na myśl epokowe dzieło Świętość oraz znaczenie, jakie jej nadał Rudolf Otto. Skojarzenie jest słuszne, jednak tylko do pewnego stopnia, bowiem pojęcie misterium tremendum u Otta obejmuje cały szereg doświadczeń, począwszy od tego, co zresztą za niemieckim myślicielem nazywa Patočka demonizmem, skończywszy na lęku, który ogarnia umysł chrześcijanina. W Świętości odnajdziemy fragment, który z pewnością wyjaśni, gdzie tkwi zasadnicza różnica:

\footnotetext{
21 Tamże.

22 Tamże, s. 143.

23 Tamże.
} 
Uczucie to [misterium tremendum] może łagodnym strumieniem przepłynąć przez jaźń w formie lekkiego, spokojnego nastroju głębokiego skupienia, może ono w ten sposób przejść w permanentne usposobienie duszy, które długo trwa i sygnalizuje swe istnienie, aż w końcu przebrzmiewa i zostawia duszę znowu sprawom świeckim. Może też wydobyć się z duszy nagle i mogą towarzyszyć mu wstrząsy i konwulsje. Może prowadzić do dziwnego podniecenia, do upojenia, zachwytu i ekstazy. Ma swoje dzikie i demoniczne formy. Może sprowadzić się do niemal upiornych dreszczy i ciarek. Ma swoje nieokrzesane i barbarzyńskie przejawy i stopnie przygotowawcze. I ma też swój rozwój w kierunku tego, co subtelne, co oczarowuje i co opromienia. Może w cichym, pokornym drżeniu i oniemieniu stanąć przed tym co... - no, przed czym? Przed tym co w niewysłowionej tajemnicy istnienie nad wszelki stworzeniem ${ }^{24}$.

Różnica wydaje się teraz oczywista. Otóż Patočce zależy na zasadniczym odróżnieniu demonicznego tremor, pełnego egzaltacji i uniesień od pokornego drżenia i oniemienia chrześcijanina wobec tajemnicy najwyższego bytu-osoby:

Tremendum, ponieważ odpowiedzialności nie odnosi się teraz do przejrzystej dla człowieka istoty dobroci i jedności, lecz do nieprzejrzystego stosunku do absolutnego, najwyższego bytu, który ma nas w garści nie pod względem zewnętrznym, lecz wewnętrznym ${ }^{25}$.

Po tym stwierdzeniu pojawia się następne:

W ostatecznej instancji dusza nie jest stosunkiem do przedmiotu, choćby najbardziej wzniosłego (jak np. platońskie dobro), lecz do osoby, która w nią patrzy, sama spojrzeniu niedostępna. Czym jest ta osoba, tego chrześcijaństwo w gruncie rzeczy nie tematyzuje ${ }^{26}$.

Element tremendum, a więc szczególny charakter czegoś, co budzi grozę, pojawia się właśnie dlatego, że współgra z chrześcijańską tajemnicą osoby, której spojrzenie przenika mnie od wewnątrz, a słowo (logos) wzywa do odpowiedzialności, do wzięcia na siebie tego, co „każdy może dokonać tylko sam w sobie, w czym nie można go zastąpić".

Takie właśnie znaczenie misterium tremendum odnajdujemy w Dziejach Apostolskich. Za każdym razem, gdy Jezus objawia się swoim uczniom, ogarnia ich strach i przerażenie. Ma ono chociażby miejsce na drodze do Damaszku, kiedy

24 R. Otto, Świętość, tłum. B. Kupis, Warszawa 1999, s. 18.

25 J. Patočka, Eseje heretyckie..., s. 145.

26 Tamże. 
rzuca na kolana św. Pawła. W tej dramatycznej scenie doszukujemy się często zwykłego „oszołomienia” światłością Bożej Mocy. Ale skupiając swoją uwagę tylko na tym elemencie, zapominamy, jakie konsekwencje miały wypowiedziane przez Jezusa słowa: „Dlaczego mnie prześladujesz?”. Szaweł, który był pierwszym z prześladowców chrześcijan, ten sam, o którym Ananiasz mówi „Panie, słyszałem z wielu stron jak dużo złego wyrządził ten człowiek świętym Twoim w Jerozolimie", odmieni swoje życie i stanie się tym, który idzie za wezwaniem Chrystusa. Jego decyzji nie sposób jednak oddzielić od świadomości tego, czym jest czyn chrześcijanina, to znaczy, czym jest Krzyż i Męka. Całe swoje życie podporządkowuje jednemu celowi: „Postanowiłem bowiem, będąc wśród was, nie znać niczego więcej, jak tylko Jezusa Chrystusa, i to ukrzyżowanego" 27.

Precyzja opowiadań o nawróceniach, w żadnym razie nie odzwierciedla przemiany życia poprzez wycofanie się ze świata i oddanie kontemplacji. Idea nawrócenia daje się doskonale wyjaśnić w pojęciach egzystencjalnych, takich jak troska, męstwo, wybór drogi życiowej, trwoga, oddanie Słowu, ofiara, śmierć. Patočka daje temu znakomity wyraz, gdy pisze o chrześcijańskim dramacie zbawienia i łaski:

Przezwyciężenie codzienności otrzymuje postać troski o zbawienie duszy, która zyskała siebie w przemianie moralnej, w zwrocie wobec śmierci i śmierci wiecznej, która żyje lękiem i nadzieją, najściślej ze sobą zespolonymi, drży pod wpływem świadomości grzechu i całą swą istotą oddaje się pokutnej ofierze ${ }^{28}$.

Już sam św. Paweł, który poświęca swoje życie trosce o zbawienie innych, które jest jednocześnie troską o własne zbawienie jest tego znakomitym przykładem.

Wybór drogi życiowej jest dla chrześcijanina zawsze wyborem drogi Krzyża, motyw Imitatio Christi konsekwencją wezwania Jezusa: „Weźmijcie moje jarzmo na siebie i uczcie się ode mnie" ${ }^{29}$. Girard wykazuje, że nakaz naśladowania Jezusa nie mógłby się pojawić „w świecie wolnym od mimetyzmu, lecz kieruje się do istot nim przesiąkniętych" ${ }^{30}$. W przypadku Tomasza z Kempis, autora słynnego dzieła $O$ naśladowaniu Chrystusa, gdzie znajdujemy jedną z najbardziej rygorystycznych propozycji życia ascetycznego, oznacza to przekształcenie własnej osobowości, w jej najgłębszych, ontologicznych wymiarach, na obraz i podobieństwo Chrystusa. Dla pierwszych chrześcijan natomiast ideałem było przyjęcie „słodkiego jarzma”, daru śmierci męczeńskiej. Ale jak wykazuje Girard, a kto wie,

\footnotetext{
271 Kor 2, 2.

28 J. Patočka, Eseje heretyckie..., s. 147.

29 Mt, 11, 29.

30 R. Girard, Widzialem szatana..., s. 27.
} 
może również Patočka, tym, co najistotniejsze w ascezie, męczeństwie i wszystkich innych staraniach odwzorowania życia Chrystusa, jest doświadczenie, „że byliśmy jego naśladowcami zawsze" 31 .

Nasza lektura doprowadziła nas zatem do pewnego punktu, w którym możemy pokusić się na ostateczne stwierdzenie. Otóż to, co dokonało się za sprawą chrześcijaństwa, ma niezwykle doniosłe znacznie antropologiczne. To właśnie idea ewangelicznej miłości prawdziwie demistyfikuje wyobrażenia człowieka o samym sobie, gdyż przywraca mu to, co decyduje o tym, kim naprawdę jest, przywraca mu człowieczeństwo oraz $\mathrm{w}$ pełni rozświetla znaczenie związane $\mathrm{z}$ tym pojęciem. Istotne jest jednak, że sama miłość, rozumiana jako osobowa relacja człowieka z Bogiem, nie pozostaje pojęta jako irracjonalna uczuciowość czy zdanie się na niewiedzę, lecz, że w swym tajemniczym majestat jest jednocześnie domeną racjonalizmu, zakorzenionego w mądrości Logosu, który przychodzi, by nas obdarzyć swoją światłością. W Liście św. Jana, który Girard nazywa prawdziwą epistemologią miłości, odnajdujemy głęboki sens tego, co staramy się tutaj uchwycić:

Kto twierdzi, że żyje w światłości, a nienawidzi brata swego, dotąd jeszcze jest w ciemności. Kto miłuje swego brata, ten trwa w światłości i nie może się potknąć. Kto zaś swojego brata nienawidzi, żyje w ciemności i działa w ciemności, i nie wie, dokąd dąży, ponieważ ciemności dotknęły ślepotą jego oczy ${ }^{32}$.

Właśnie w tych słowach zostaje ujęta istota bycia człowiekiem. Prawda, o której wspomina Jan, wymyka się czysto intelektualnemu zrozumieniu, ale w tym sensie, w jakim odrywa się ono od przykazania miłości. Patočka pisze, że chrześcijaństwo nie tematyzuje ostatecznie tego, kim jest osoba. Być może jest to celowy zabieg Ewangelii. Prawdopodobnie dlatego też nie odnajdujemy żadnych opisów cech Jezusa, jego nawyków, usposobienia. Wiemy jedynie, że jest Synem Bożym, który przyszedł do ludzi, by dać im światło zbawienia. I jeśli nasze oczy nie są na uwięzi, jak oczy Jego uczniów, którzy Go nie poznali w drodze do Emaus, to znaczy, jeśli nie uważamy Go za martwego, to rzeczywiście rozpoznajemy w Nim Mądrość, będącą tożsamą z Jego Słowem i Czynem, a która stanowi wieczny ślad Jego obecności wśród nas.

Ale jest jeszcze jeden istotny moment, który płynie z tej nauki. Chrześcijaństwo nie toleruje znieruchomienia prawdy. Jest ona zawsze niedostępna. Jest misterium tremendum. Logos z Ewangelii św. Jana jest Słowem, które „pprzyszło

\footnotetext{
31 Tamże.

32 J 2, 9-11.
} 
do swojej własności, a swoi Go nie przyjęli" ${ }^{33}$. W świecie chrześcijańskim dramat upadku polega na tym, że próba odczytania owej Mądrości łączy się nieustannie z jej nierozpoznaniem, z ekspulsją i ukrzyżowaniem.

\section{Who is man? Girard and Patočka on rising after falling Summary}

This article studies the philosophical connection between René Girard and Jan Patočka. It examines the ethical and anthropological perspectives of both philosophers. To illustrate this, the author re-reads the Biblical story about the adulterous woman and the symbolism of the first stone, then, on the basis of this story, he shows the specificity of the Gospel's ethics in relation to mythology and demonism present in archaic cultures. The paper also analyzes fundamental ethical concepts like violence, desire (epithymia), responsibility and mimesis.

\section{Bibliografia}

Derrida J., Herezja, tajemnica i odpowiedzialność: Europa Jana Patočki, tłum. A. Drop, „Logos i Etos”, 1/1993, s. 138.

Durkheim E., Les formes elemetaires de la vie religieuse, Paris 1968.

Girard R., Kozioł ofiarny, tłum. M. Goszczyńska, Łódź 1987.

Girard R., Rzeczy ukryte od założenia świata, tłum. M. Goszczyńska, „Literatura na świecie", nr 12 (149).

Girard R., Sacrum i przemoc. Cześć pierwsza, przeł. M. i J. Plecińscy, Poznań 1993.

Girard R., Widziałem szatana spadajacego z nieba jak błyskawica, tłum. E. Burska, Warszawa 2002.

Otto R., Świętość, tłum. B. Kupis, Warszawa 1999.

Patočka J., Eseje heretyckie z filozofii dziejów, tłum. J. Zychowicz, Warszawa 1998.

Platon, Fajdros, tłum. W. Witwicki, Warszawa 2004.

Bogumił Strączek, mgr, doktorant, Wydział Filozoficzny, Katedra Filozofii Kultury, Akademia Ignatianum w Krakowie; bogumil.straczek@wp.pl

$33 \mathrm{~J} 1,5$. 
